\title{
Edible insects as a food source: a review
}

\author{
Chufei Tang ${ }^{1,2}$, Ding Yang ${ }^{2}$, Huaijian Liao ${ }^{1^{*}}$ (D) Hongwu Sun ${ }^{3 *}$, Chuanjing Liu ${ }^{4}$, Lanjun Wei ${ }^{1}$ and Fanfan Li ${ }^{1}$
}

\begin{abstract}
The practice of eating insects has been documented for a long time. With obvious economic and environmental advantages, edible insects are in the spotlight recently due to their enormous potential in multiple industries. A number of research has been conducted to maximize their value, but concerns have been raised for the food security. In this review, we compared the characteristics of edible insects with other traditional protein sources. The progress of modern entomophagy was introduced. The benefits and risks of eating insects were summarized. Additionally, the shortcoming of current production were discussed. Feasible ways and strategies were proposed to promote the consumption of edible insects.
\end{abstract}

Keywords: Edible insects, Modern entomophagy, Consumption, Promotion

\section{Introduction}

The consumption of edible insects started nearly 7000 years ago (Ramos-Elorduy 2009). More than 2300 species of 18 orders have been reported as edible insects, of which 5 orders are with at least 100 records. These insects inhabit in both aquatic and terrestrial environments (Jongema 2017). The majority of them are harvested from nature though some species are farmed in a large scale.

Many insects have been eaten worldwide (Van Huis et al. 2013). Lepidopterans, Orthopterans, Isopterans and Hymenopterans are all regarded as common food sources in many areas. Culturally and religiously, entomophagy is particularly popular in tropical and subtropical regions due to the warm and moist climate (Jongema 2017). Tropical insects are generally large in size with stable life history, which can facilitate harvesting (Gaston \& Chown 1999; Janzen \& Schoener 1968). The immature forms of insects (pupae and larvae) are preferred for their abundant amino acids and fatty acids, which not only ensure the nutritional value, but also provide a unique and splendid flavor.

The production of animal protein is under huge pressure as the world population is rapidly increasing (Gerland et al. 2014; Godfray et al. 2010). Consequently, people are facing the enduring protein undernourishment and seeking alternative protein resources. Entomophagy is seen as

\footnotetext{
*Correspondence: huaixiyu_08@126.com; sunhw0617@sina.com ${ }^{1}$ Institute of Leisure Agriculture, Jiangsu Academy of Agricultural Sciences, Nanjing 210014, China

3 Jiangsu Academy of Agricultural Sciences, Nanjing 210014, China Full list of author information is available at the end of the article
}

one of the best choices. As it could provide large amounts of multiple nutrients rapidly, it might provide a solution to address famine (Van Huis 2013). Great attention has been paid to the utilization and production of edible insects. Increasing number of people are joining the industry. However, the industrial chain of edible insects, from fundamental research to marketing, still needs to be developed.

\section{Nutritional value}

Overall, insects have obvious advantages in nutritional value. Their nutritional compositions are actually quite similar to those of the traditional animal foods (Raubenheimer \& Rothman 2013). They have enormous potential as a source of nutrients and active substances not only for human, but also for poultry.

Insects at all life stages are rich sources of animal protein. The amino acid spectra of edible insects are shown in Table 1. The proportion of crude protein is generally from 40 to $75 \%$ based on dry weight basis, with the average values per order from 33 to $60 \%$. Edible insects usually contain more crude protein compared with the conventional meat, though their amino acid compositions are usually analogous. As food, they can provide essential amino acids at an ideal level, which are generally 76 to $96 \%$ digestible (Belluco et al. 2015; Bukkens 1997; Nowak et al. 2016; Payne et al. 2016; RamosElorduy et al. 1997). The essential and semi-essential amino-acid contents of commonly eaten species are shown with the amino acid requirements for adults 
Table 1 Amino acid content of common edible insects (\% in crude protein of dry weight)

\begin{tabular}{|c|c|c|c|c|c|c|c|c|c|c|c|c|c|c|}
\hline \multirow[t]{2}{*}{ Name } & \multirow[t]{2}{*}{ Stage/Part } & \multirow{2}{*}{$\begin{array}{l}\text { Crude } \\
\text { protein } \\
(\%)\end{array}$} & \multicolumn{8}{|c|}{ Essential } & \multicolumn{4}{|c|}{ Semi-essential } \\
\hline & & & Ile & Leu & Lys & Met & Phe & Thr & Trp & Val & $\operatorname{Arg}$ & $\mathrm{His}$ & Cys & Tyr \\
\hline Blattodea (cockroach) & & 68.33 & 4.57 & 7.77 & 7.80 & 3.13 & 4.60 & 4.93 & 0.97 & 7.70 & 7.43 & 3.13 & 1.23 & 8.93 \\
\hline Blatta lateralis & Nymph & 76.00 & 7.70 & 12.00 & 12.80 & 3.40 & 7.70 & 7.90 & 1.70 & 12.30 & 14.00 & 5.50 & 1.40 & 14.30 \\
\hline Periplaneta americana & Adult & 66.00 & 3.10 & 5.60 & 5.00 & 3.60 & 3.10 & 3.60 & 0.60 & 6.50 & 5.10 & 2.00 & 2.00 & 6.90 \\
\hline Periplaneta australasiae & Adult & 63.00 & 2.90 & 5.70 & 5.60 & 2.40 & 3.00 & 3.30 & 0.60 & 4.30 & 3.20 & 1.90 & 0.30 & 5.60 \\
\hline Coleoptera & & 41.75 & 5.58 & 8.13 & 5.55 & 1.38 & 3.68 & 3.25 & 0.78 & 5.90 & 5.10 & 2.60 & 1.13 & 4.50 \\
\hline $\begin{array}{l}\text { Callipogon barbatus (longhorned } \\
\text { beetle) }\end{array}$ & Larva & 41.00 & 5.80 & 10.00 & 5.70 & 2.00 & 4.70 & 4.00 & 0.70 & 7.00 & 5.90 & 2.00 & 2.00 & 4.20 \\
\hline $\begin{array}{l}\text { Rhynchophorus phoenicis (African palm } \\
\text { weevil) }\end{array}$ & Larva & 33.00 & 7.80 & 5.90 & 6.40 & 1.20 & 3.30 & 1.40 & 0.50 & 5.50 & & & 1.10 & 1.40 \\
\hline $\begin{array}{l}\text { Tenebrio molitor (Yellow mealworm } \\
\text { beetle) }\end{array}$ & Larva & 48.00 & 4.00 & 6.90 & 4.90 & 1.20 & 3.20 & 3.60 & 1.00 & 5.90 & 4.50 & 2.70 & 0.60 & 5.40 \\
\hline Zophobas morio (superworm) & Larva & 45.00 & 4.70 & 9.70 & 5.20 & 1.10 & 3.50 & 4.00 & 0.90 & 5.20 & 4.90 & 3.10 & 0.80 & 7.00 \\
\hline Diptera & & 48.80 & 3.74 & 6.48 & 5.74 & 2.00 & 4.76 & 3.98 & 1.43 & 5.12 & 5.05 & 2.38 & 0.83 & 5.52 \\
\hline Copestylum anna (hoverfly) & Larva & 37.00 & 4.00 & 7.40 & 5.50 & 1.90 & 5.40 & 4.90 & 0.70 & 6.10 & 6.30 & 2.90 & 1.80 & 6.60 \\
\hline Ephydra hians & Larva & 42.00 & 4.00 & 7.40 & 5.50 & 1.90 & 5.40 & 4.90 & 0.70 & 6.10 & & 1.00 & & 5.10 \\
\hline Hermetia illucens (soldier fly) & Larva & 49.00 & 4.00 & 6.60 & 5.60 & 1.40 & 3.80 & 3.60 & 1.10 & 5.60 & 4.80 & 2.60 & 0.70 & 6.00 \\
\hline Musca domestica (house fly) & Pupa & 62.00 & 3.50 & 5.30 & 5.20 & 2.60 & 4.20 & 3.20 & & 3.40 & 4.20 & 2.60 & 0.40 & 4.80 \\
\hline Musca domestica (house fly) & Larva & 54.00 & 3.20 & 5.70 & 6.90 & 2.20 & 5.00 & 3.30 & 3.20 & 4.40 & 4.90 & 2.80 & 0.40 & 5.10 \\
\hline Hemiptera & & 48.83 & 3.93 & 6.45 & 3.93 & 2.78 & 5.93 & 3.90 & 0.78 & 5.38 & 3.76 & 2.50 & 1.80 & 5.62 \\
\hline Aspongubus viduatus (melon bug) & Adult & 27.00 & 2.10 & 2.30 & 1.60 & 3.60 & 1.10 & 1.80 & & 2.60 & 1.30 & 2.10 & 2.10 & 1.70 \\
\hline Euschistus egglestoni (stink bug) & Adult & 46.00 & 4.40 & 7.00 & 3.00 & 2.80 & 3.30 & 4.80 & 0.60 & 6.10 & 4.30 & 3.20 & 1.00 & 4.80 \\
\hline $\begin{array}{l}\text { Hoplophorion monograr } \\
\text { (treehopper) }\end{array}$ & Adult & 62.00 & 4.10 & 7.70 & 5.30 & 1.90 & 4.70 & 4.50 & 1.00 & 7.40 & 4.50 & 1.50 & 2.10 & 9.00 \\
\hline Krizousacorixa azteca (waterboatman) & eggs & 64.00 & 5.00 & 8.00 & 3.50 & 2.90 & 6.20 & 4.00 & 1.10 & 6.00 & & & & \\
\hline Pachilis gigas & Adult & 65.00 & 4.20 & 6.90 & 4.50 & 3.60 & 14.40 & 3.60 & 0.60 & 6.20 & 4.10 & 2.00 & 2.40 & 5.80 \\
\hline Umbonia reclinata & Adult & 29.00 & 3.80 & 6.80 & 5.70 & 1.90 & 5.90 & 4.70 & 0.60 & 4.00 & 4.60 & 3.70 & 1.40 & 6.80 \\
\hline Hymenoptera & & 51.43 & 5.20 & 8.27 & 6.27 & 1.85 & 2.60 & 4.70 & 0.39 & 6.10 & 5.03 & 2.61 & 1.60 & 4.87 \\
\hline Apis mellifera (honeybee) & Adult & 51.00 & 5.60 & 9.60 & 6.60 & & 0.90 & 5.50 & 0.00 & 6.90 & 5.90 & 2.50 & 1.70 & 4.50 \\
\hline Apis mellifera (honeybee) & Pupa & 49.00 & 5.60 & 7.70 & 7.30 & & 0.50 & 4.60 & 0.00 & 5.90 & 5.60 & 2.70 & 1.00 & 4.90 \\
\hline Apis mellifera (honeybee) & Larva & 42.00 & 6.00 & 9.40 & 7.00 & & 0.80 & 6.10 & 0.00 & 6.20 & 6.00 & 2.60 & 1.30 & 2.00 \\
\hline Atta mexicana (leafcu & Adult & 58.00 & 5.30 & 8.00 & 4.90 & 1.90 & 4.10 & 4.30 & 0.60 & 6.40 & 4.70 & 2.50 & 1.50 & 4.70 \\
\hline Brachygastra azteca (wasp) & Pupa & 70.00 & 5.10 & 8.50 & 6.10 & 1.40 & 4.10 & 4.40 & 0.70 & 6.40 & 4.40 & 2.80 & 1.60 & 6.50 \\
\hline Parachartegus apicalis (wasp) & Pupa & 50.00 & 4.20 & 7.70 & 5.80 & 2.00 & 4.30 & 4.70 & 0.50 & 5.70 & 4.30 & 2.90 & 2.00 & 7.10 \\
\hline Bee brood & $\begin{array}{l}\text { Immature } \\
\text { stages }\end{array}$ & 40.00 & 4.60 & 7.00 & 6.20 & 2.10 & 3.50 & 3.30 & 0.90 & 5.20 & 4.30 & 2.30 & 2.10 & 4.40 \\
\hline Isoptera (termite) & & 33.00 & 5.10 & 7.80 & 5.40 & 0.80 & 4.40 & 2.80 & 1.40 & 7.30 & 6.90 & 5.10 & 1.90 & 3.00 \\
\hline Macrotermes bellicosus & $\begin{array}{l}\text { Dewinged } \\
\text { adults }\end{array}$ & 33.00 & 5.10 & 7.80 & 5.40 & 0.80 & 4.40 & 2.80 & 1.40 & 7.30 & 6.90 & 5.10 & 1.90 & 3.00 \\
\hline Lepidoptera & & 65.25 & 4.58 & 6.45 & 6.33 & 1.38 & 5.10 & 3.75 & 1.00 & 7.45 & 4.17 & 1.50 & 1.23 & \\
\hline Anaphe venata (African silkworm) & Larva & 58.00 & 2.10 & 1.30 & 0.90 & 0.00 & 2.10 & 0.40 & 0.00 & 1.80 & 0.30 & 0.80 & 0.00 & 2.50 \\
\hline $\begin{array}{l}\text { Imbrasia epimethea (mopane } \\
\text { caterpillar) }\end{array}$ & Larva & 62.00 & 2.90 & 8.10 & 7.40 & 2.20 & 6.50 & 4.80 & 1.60 & 10.20 & 6.60 & 2.00 & 1.90 & 7.50 \\
\hline Imbrasia truncata (mopane caterpillar) & Larva & 65.00 & 2.40 & 7.30 & 7.90 & 2.20 & 6.20 & 4.70 & 1.70 & 10.20 & 5.60 & 1.70 & 1.70 & 7.60 \\
\hline Usta terpsichore (mopane caterpillar) & Larva & 76.00 & 10.90 & 9.10 & 9.10 & 1.10 & 5.60 & 5.10 & 0.70 & 7.60 & & & 1.30 & 3.30 \\
\hline Orthoptera & & 59.17 & 3.98 & 7.40 & 5.12 & 1.45 & 4.37 & 3.53 & 0.65 & 5.12 & 5.35 & 1.93 & 1.30 & \\
\hline
\end{tabular}


Table 1 Amino acid content of common edible insects (\% in crude protein of dry weight) (Continued)

\begin{tabular}{|c|c|c|c|c|c|c|c|c|c|c|c|c|c|c|}
\hline \multirow[t]{2}{*}{ Name } & \multirow[t]{2}{*}{ Stage/Part } & \multirow{2}{*}{$\begin{array}{l}\text { Crude } \\
\text { protein } \\
(\%)\end{array}$} & \multicolumn{8}{|c|}{ Essential } & \multicolumn{4}{|c|}{ Semi-essential } \\
\hline & & & lle & Leu & Lys & Met & Phe & Thr & Trp & Val & $\operatorname{Arg}$ & His & Cys & Tyr \\
\hline Acheta domesticus (cricket) & Adult & 62.00 & 2.60 & 4.50 & 3.50 & 0.90 & 1.40 & 2.20 & 0.40 & 3.70 & 3.70 & 1.60 & & 2.50 \\
\hline Boopedon flaviventris (boopies) & Adult & 56.00 & 4.70 & 8.80 & 5.50 & 1.80 & 4.10 & 4.40 & 0.60 & 5.70 & 4.30 & 2.40 & 2.00 & 7.40 \\
\hline Gryllus assimilis (cricket) & Adult & 56.00 & 3.40 & 6.60 & 5.00 & 1.20 & 2.90 & 3.30 & 0.70 & 5.30 & 5.80 & 2.10 & 0.50 & 4.50 \\
\hline Gryllodes silligatus (cricket) & Nymph & 56.00 & 3.70 & 6.90 & 5.30 & 1.60 & 3.10 & 3.50 & 0.90 & 5.20 & 5.70 & 2.20 & 0.90 & 4.20 \\
\hline Sphenarium histrio (grasshopper) & Adult & 60.00 & 5.30 & 8.70 & 5.70 & 0.70 & 4.40 & 4.00 & 0.60 & 5.10 & 6.60 & 1.10 & 1.30 & 7.30 \\
\hline $\begin{array}{l}\text { Sphenarium purpurascens } \\
\text { (grasshopper) }\end{array}$ & Adult & 65.00 & 4.20 & 8.90 & 5.70 & 2.50 & 10.30 & 3.80 & 0.70 & 5.70 & 6.00 & 2.20 & 1.80 & 6.30 \\
\hline \multicolumn{15}{|l|}{ Common Meat } \\
\hline Beef & & & 5.10 & 8.40 & 8.40 & 2.30 & 4.00 & 4.00 & & 5.70 & 6.60 & 2.90 & 1.40 & 3.20 \\
\hline Pork & & & 4.90 & 7.50 & 7.90 & 2.50 & 4.10 & 5.10 & & 5.00 & 6.40 & 3.20 & 1.30 & 3.00 \\
\hline Chicken & Broiler, breast & & 4.20 & 6.90 & 7.80 & 2.10 & 2.50 & 3.70 & & 4.60 & 6.40 & 4.40 & & 3.50 \\
\hline $\begin{array}{l}\text { Amino acid requirement in human } \\
\text { nutrition (mg) }\end{array}$ & & & 30.00 & 59.00 & 45.00 & 16.00 & & 23.00 & 6.00 & 39.00 & & 15.00 & 16.00 & \\
\hline
\end{tabular}

The average data of each order are bold. The data were summarized by the following references: Józefiak et al. 2016, Kulma et al. 2016, Finke 2005, 2013, Mariod et al. 2011, Van Huis et al. 2013, Belluco et al. 2013, Ramos-Elorduy et al. 1997, Rumpold and Schluter 2013. Mean values are shown if multiple different reports exist

Ile Isoleucine, Leu Leucine, Lys Lysine, Met Methionine, Cys Cysteine, Phe Phenylalanine, Tyr Tyrosine, Thr Threonine, Trp Tryptophan, Val Valine, Arg Arginine, His Histidine

published by the World Health Organization (WHO 2007). Some insects lack or only contain very low amounts of methionine, cysteine and tryptophan. The diet needs to be balanced if these insects are taken as the majority of a meal. But aside from these species, insects generally meet the WHO recommendation for amino acids. Most of them can provide satisfactory amounts of essential amino acids by consuming a reasonable combination of products. All groups are eligible with adequate isoleucine, leucine, lysine, phenylalanine, threonine, valine, arginine, histidine and tyrosine. The amount of lysine, valine, methionine, arginine and tyrosine is generally the richest in Blattodea compared with other insects. The amount of leucine in Coleoptera is higher than that in other types of protein sources including livestock. Similarly, the amount of phenylalanine in Hemiptera is generally higher than that in all other known protein sources. Compared with edible insects at other stages, nymphs are usually the most abundant source of nearly all kinds of amino acids. They are especially rich in arginine which benefits heart and blood vessel conditions and boosts the immune system. Arginine is more than twice as abundant in nymphs of cockroaches (Blatta lateralis) as in beef and pork.

Insects are generally abundant with fats. The fatty acid spectra of common edible insects based on dry matter from literatures are concluded in Table 2. Aside from the acids listed in the table, trace amounts of other acids have been found from some insects, including the oddnumbered fatty acids, the even numbered saturated fatty acids and some unsaturated fatty acids. These acids are considered to be negligible. The fat content of insects in immature stages varies from 8 to $70 \%$ based on dry weight. The fatty acid compositions are similar in different sources of meat, including all groups of insects (Bukkens 1997). The fat contents of Lepidopteran and Heteropteran larvae are higher than that of other edible insects. Larvae are the best source of fatty acids or oil compared with insects at other stages. The adults are overall slim with a fat content less than $20 \%$. The fat in insects is mainly triacylglycerol (Arrese \& Soulages 2010). Saturated fatty acids (SFAs) and monounsaturated fatty acids (MUFAs) usually compose more than $80 \%$ of all fats. The SFAs in insects at different stages are mostly composed by palmitic acid and stearic acid. The content of SFAs is usually higher than that of MUFAs among adults, whereas the latter is healthier for human diets. Oleic acid, a common monounsaturated fatty acid in human diet, is the most MUFAs in insects. It helps to reduce blood pressure for human-being and has great potential in curing inflammatory, immune and cardiovascular diseases (Sales-Campos et al. 2013). With the risk of overtaking SFAs as food, however, the mature insects are the best source of polyunsaturated fatty acids (PUFAs) compared with pork, beef and insects at other stages. Linoleic acid is the major ingredient of PUFAs in insects, which has been proven to be anti-inflammatory, acne reductive and skin-lightening. Orthoptera is the best source of linoleic acid compared with other orders of insects. Lepidotera, with high amounts of PUFAs, is especially rich in $\alpha$-Linolenic acid, which has been identified as a potential nutraceutical to protect the brain 
Table 2 Fat content (\%) of common edible insects (\% in crude fat of dry weight)

\begin{tabular}{|c|c|c|c|c|c|c|c|c|c|c|c|c|}
\hline \multirow[t]{2}{*}{ Name } & \multirow[t]{2}{*}{ Stage/Part } & \multirow[t]{2}{*}{$\begin{array}{l}\text { Crude } \\
\text { fat (\%) }\end{array}$} & \multicolumn{4}{|c|}{ Saturated fatty acids } & \multicolumn{3}{|c|}{$\begin{array}{l}\text { Monounsaturated fatty } \\
\text { acids }\end{array}$} & \multicolumn{3}{|c|}{$\begin{array}{l}\text { Polyunsaturated fatty } \\
\text { acids (EFA) }\end{array}$} \\
\hline & & & $\begin{array}{l}\text { Total } \\
\text { SFA }\end{array}$ & C14:0 & C16:0 & $\mathrm{C} 18: 0$ & $\begin{array}{l}\text { Total } \\
\text { MUFA }\end{array}$ & $\begin{array}{l}\text { C16:1 } \\
\text { n7 }\end{array}$ & $\begin{array}{l}\text { C18:1 } \\
\text { n9 }\end{array}$ & $\begin{array}{l}\text { Total } \\
\text { PUFA }\end{array}$ & $\begin{array}{l}\text { C18:2 } \\
\text { n6 }\end{array}$ & $\begin{array}{l}\mathrm{C} 18: 3 \\
\mathrm{n} 3\end{array}$ \\
\hline Blattodea (cockroach) & & 25.05 & 37.18 & 1.22 & 23.13 & 11.41 & 45.02 & 2.33 & 41.88 & 17.85 & 16.43 & 0.75 \\
\hline Blatta lateralis & Nymph & 21.90 & 48.30 & 1.90 & 26.80 & 18.10 & 42.20 & 3.30 & 38.00 & 9.60 & 8.70 & 0.70 \\
\hline Periplaneta americana & Nymph & 28.20 & 26.07 & 0.54 & 19.47 & 4.72 & 47.84 & 1.35 & 45.76 & 26.09 & 24.17 & 0.79 \\
\hline Coleoptera & & 35.81 & 37.68 & 1.62 & 29.77 & 5.40 & 53.12 & 7.32 & 44.91 & 13.01 & 11.61 & 0.99 \\
\hline Copris nevinsoni & Larva & 13.60 & 44.02 & 1.76 & 28.97 & 13.29 & 50.41 & 2.75 & 47.66 & 5.57 & 3.92 & 0.84 \\
\hline Rhynchophorus phoenicis (African palm weevil) & Larva & 50.23 & 39.90 & 2.85 & 34.20 & 1.70 & 55.00 & 19.65 & 35.05 & 22.85 & 19.50 & 2.75 \\
\hline Tenebrio molitor (Yellow mealworm beetle) & Larva & 38.00 & 30.12 & 0.39 & 28.20 & 0.89 & 66.77 & 5.98 & 60.63 & 3.11 & 2.84 & 0.18 \\
\hline Zophobas morio (superworm) & Larva & 41.42 & 36.69 & 1.47 & 27.70 & 5.70 & 40.31 & 0.91 & 36.29 & 20.51 & 20.19 & 0.18 \\
\hline Diptera & & 21.94 & 45.74 & 6.63 & 22.53 & 2.18 & 34.65 & 16.87 & 17.63 & 16.04 & 15.08 & 0.88 \\
\hline Hermetia illucens (soldier fly) & Larva & 26.00 & 67.93 & 9.87 & 13.25 & 2.02 & 17.39 & 4.08 & 12.84 & 14.67 & 13.91 & 0.53 \\
\hline Musca domestica (house fly) & Pupa & 15.50 & 33.40 & 3.20 & 27.60 & 2.20 & 38.90 & 20.60 & 18.30 & 17.00 & 14.90 & 2.10 \\
\hline Musca domestica (house fly) & Larva & 24.31 & 35.89 & 6.83 & 26.74 & 2.31 & 47.67 & 25.92 & 21.75 & 16.44 & 16.44 & 0.00 \\
\hline Hemiptera & & 32.25 & 45.44 & 1.17 & 11.42 & 32.33 & 21.75 & 5.45 & 17.91 & 34.17 & 4.90 & 0.45 \\
\hline Aspongubus viduatus (melon bug) & Adult & 54.20 & 37.87 & 0.34 & 31.33 & 3.47 & 56.78 & 10.62 & 45.53 & 5.35 & 4.90 & 0.45 \\
\hline Tessaratoma papillosa & & 23.55 & 41.46 & & 0.46 & 41.00 & 7.27 & & 7.27 & 53.35 & & \\
\hline Meimuna opalifera & Adult & 19.00 & 56.99 & 1.99 & 2.47 & 52.53 & 1.20 & 0.28 & 0.92 & 43.80 & & \\
\hline Hymenoptera & & 18.71 & 34.58 & 1.54 & 23.83 & 8.46 & 50.97 & 2.57 & 43.99 & 4.07 & 3.39 & 0.60 \\
\hline Apis mellifera (honeybee) & Adult & 12.30 & 25.20 & 0.60 & 14.40 & 9.30 & 67.00 & 2.60 & 45.20 & 7.80 & 7.80 & \\
\hline Apis mellifera (honeybee) & Pupa & 20.10 & 51.10 & 2.90 & 35.10 & 12.60 & 48.90 & 0.60 & 47.60 & & & \\
\hline Apis mellifera (honeybee) & Larva & 18.91 & 51.80 & 2.40 & 37.30 & 11.80 & 48.20 & 0.70 & 47.50 & & & \\
\hline Polyrhachis vicina (ant) & Pupa & 22.00 & 24.10 & 0.60 & 17.67 & 4.30 & 72.27 & 8.77 & 61.43 & 3.60 & 2.07 & 0.80 \\
\hline Bee brood & Immature stages & 20.25 & 20.70 & 1.20 & 14.70 & 4.30 & 18.50 & 0.20 & 18.20 & 0.80 & 0.30 & 0.40 \\
\hline Isoptera (termite) & & 36.80 & 48.98 & 2.17 & 42.45 & 2.86 & 17.94 & 2.10 & 15.84 & 33.08 & 24.24 & 3.90 \\
\hline Macrotermes bellicosus & Dewinged adults & 36.80 & 48.98 & 2.17 & 42.45 & 2.86 & 17.94 & 2.10 & 15.84 & 33.08 & 24.24 & 3.90 \\
\hline Lepidoptera & & 37.95 & 36.42 & 0.36 & 26.92 & 9.11 & 22.60 & 1.37 & 21.23 & 40.57 & 6.51 & 33.94 \\
\hline $\begin{array}{l}\text { Bombyx mori (domesticated } \\
\text { silkworm) }\end{array}$ & Pupa & 35.00 & 28.80 & 0.10 & 24.20 & 4.50 & 27.70 & 1.70 & 26.00 & 43.60 & 7.30 & 36.30 \\
\hline Imbrasia belina (mopane caterpillar) & Larva & 23.38 & 37.88 & 1.15 & 31.90 & 4.71 & 36.00 & 1.80 & 34.20 & 26.12 & 6.02 & 19.60 \\
\hline $\begin{array}{l}\text { Imbrasia truncata (mopane } \\
\text { caterpillar) }\end{array}$ & Larva & 16.40 & 46.50 & 0.20 & 24.60 & 21.70 & 7.60 & 0.20 & 7.40 & 44.40 & 7.60 & 36.80 \\
\hline Samia ricinii (mopane caterpillar) & Larva & 77.00 & 32.50 & 0.00 & 26.97 & 5.53 & 19.10 & 1.78 & 17.33 & 48.17 & 5.11 & 43.06 \\
\hline Orthoptera & & 19.92 & 35.17 & 13.86 & 20.65 & 0.67 & 18.81 & 1.56 & 17.25 & 46.14 & 32.20 & 1.70 \\
\hline Acheta confirmata (cricket) & Adult & 21.14 & 32.80 & 26.10 & 5.50 & 1.20 & 33.50 & 2.40 & 31.10 & 33.90 & 32.20 & 1.70 \\
\hline Brachytrupes portentosus & Adult & 18.70 & 37.53 & 1.61 & 35.79 & 0.13 & 4.11 & 0.71 & 3.40 & 58.37 & & \\
\hline \multicolumn{13}{|l|}{ Common meat } \\
\hline Beef & & & 32.25 & 0.77 & 16.74 & 9.53 & 18.83 & & 10.52 & 49.08 & 36.10 & 6.16 \\
\hline Pork & & & 41.04 & 3.43 & 21.68 & 12.71 & 43.04 & 2.93 & 39.39 & 16.00 & 7.29 & 1.71 \\
\hline Chicken & & & 33.33 & 1.33 & 22.67 & 8.00 & 46.67 & 0.27 & 41.33 & 20.00 & 14.00 & 0.67 \\
\hline $\begin{array}{l}\text { Fatty acid requirement in human } \\
\text { nutrition }(\mathrm{g})\end{array}$ & & & 26.90 & & & & 30.85 & & & 16.90 & 14.95 & 1.50 \\
\hline
\end{tabular}

SFA Saturated fatty acids: C14:0, myristic acid; C16:0, palmitic acid; C18:0, stearic acid. MUFA: C16:1 n7 - palmitoleic acid; C18:1 n9 - oleic acid. PUFA: C18:2 n6 - linoleic acid; C18:3 n3 - a-linolenic acid. The average data of each order are bold. The data were summarized by the following references: Elmadfa and Kornsteiner 2009, Wood et al. 2004, Józefiak et al. 2016, Kulma et al. 2016, Finke 2005, 2013, Mariod et al. 2011, Van Huis et al. 2013, Belluco et al. 2013,

Rumpold and Schluter 2013. Mean values are shown if multiple different reports exist

from stroke (Blondeau et al. 2015). Both linolenic acid and $\alpha$-Linolenic acid are essential for human-being as they cannot be produced by ourselves. They are precursors for the synthesis of prostaglandin, thromboxane and leukotriene and are essential in maintaining normal visual functions. Inadequate intake of linolenic 
and $\alpha$-Linolenic acids can cause growth retardation, reproductive disorders, skin damage (rash, etc.) as well as the diseases of kidney, liver, neurological and visual systems for human. Extracting these nutritious ingredients from insects has great potential in medical industry.

Insects are great resources of vitamins and micronutrients though some studies pointed out these contents can be affected by feeding. They could provide biochemical substances such as vitamins $A, B_{1-12}, C, D, E, K$, which are needed for normal growth and health (Kouřimská \& Adámková 2016). For example, caterpillars are especially rich in $B_{1}, B_{2}$ and $B_{6}$ (Rumpold \& Schluter 2013). Bee brood (pupae) is rich in vitamins A and D (Finke 2005). Red palm weevil (Rhynchophorus ferrugineus) is a good source of vitamin E (Bukkens \& Paoletti 2005). A variety of micronutrients could be found in edible insects, including iron, magnesium, manganese, phosphorous, potassium, selenium, sodium and zinc (Rumpold \& Schluter 2013). Compositions of common and trace mineral elements in insects based on dry weight are summarized in Table 3. The contents of mineral elements in different insects all differ significantly. Most insects only contain a low amount of Calcium (less than $100 \mathrm{mg} / \mathrm{g}$ based on dry matter), but larvae of house flies and adults of melon bugs are typically abundant with it. Pupae of Polybia occidentalis can only provide $54 \mathrm{mg}$ of potassium per $100 \mathrm{~g}$ while all stages of Apis mellifera, which also belongs to Hymenoptera, can provide at least $1500 \mathrm{mg}$ of potassium per $100 \mathrm{~g}$. Adults of Macrotermes nigeriensis only provide $6.1 \mathrm{mg}$ of magnesium per $100 \mathrm{~g}$ while those of Euschistus egglestoni provide $1910 \mathrm{mg}$ of that per $100 \mathrm{~g}$. The contents of trace elements in insects differ distinctly, too. Most edible insects are however, particularly abundant with iron. The account that iron takes in insects is usually higher than that in fresh beef.

In the meantime, edible insects have great value in supplying calories with caloric contributions vary from 290 to more than $750 \mathrm{kcal} / 100 \mathrm{~g}$ (Ramos-Elorduy et al. 1997). Generally, adults are composed of a high amount of chitin which is indigestible, and are thus low in calories. Larvae and pupae are usually composed of high amounts of proteins and fats, corresponding to high calories. Hence, products made from insects of different stages can fit people with different needs.

Notably, nutritional value is not equal to health assessment. A healthy food should be balanced between energy and its nutritional composition.

\section{Modern entomophagy}

There are six common commercial edible insect species at present, including cricket (Acheta domesticus), honeybee (Apis mellifera), domesticated silkworm (Bombyx mori), mopane caterpillar (Imbrasia belina), African palm weevil (Rhynchoporus phoenicis) and yellow meal worm (Tenebrio molitor).

For some of them, only larvae are typically consumed (R. phoenicis, T. molitor and I. belina) as their abundant fats can provide a mesmerizing flavor. The production of $T$. molitor has been industrialized because of its vitality. They can grow massively and rapidly even if only dry low-nutritional waste is used as feeds (Ramos-Elorduy \& Moreno 2002). For orthopterans like cricket, usually only adults would be eaten. They are particularly easy to harvest from swarming. However, as they are important pests in many areas and are often exposed to pesticides during their whole life cycle, it is concerned that they might contain residual pesticides that can cause food safety issues.

Silkworm has a long history of domestication, especially in Asia. Silk, the primary product that silkworms are raised for, established the earliest trade between China and Mediterranean area. Sericulture still makes great profits in global scale nowadays. However, silk is not the only remarkable product made from silkworms, whose pupae are traditionally consumed as food (Zhang et al. 2008). They are not only popular in China, but also in Japan, Thailand and Vietnam, and possibly, many other countries in the future.

Honeybees have been raised as pollinators and they are esculent at nearly all stages. Extracts of bee brood are luxury nourishments in Asia (Chen et al. 1998). Some people take hive (honeybag) as a nutritional delicacy and a good source of sugar (Cherry 1991; O'Dea 1991). Honey of course, has been a popular condiment all over the world. But it is not the only entomic sugar that is popular now. Actually, a newly developed product called lerp, which is the secretion produced by larvae of psyllids, is becoming particularly vogue. Besides monosaccharides and water-insoluble carbohydrates, it is abundant with minerals, especially potassium and phosphorous (Ernst \& Sekhwela 1987). However, as people can only collect it from the host plants infected with corresponding psyllids, its production still relies on nature (Van Huis et al. 2013; Yen 2002).

Consuming insects wisely and healthily has become a trendy solution to poverty. Edible insects are playing an important role in various food systems. In fact, they have been a vital source of essential nutrients in many developing regions. Many people are still under economic pressure and are therefore malnourished. Practically, it is easier to adjust their traditional food systems rather than force them to follow unfamiliar foreign diets. A project called WinFood, targeting at alleviating childhood malnutrition, has thus been launched and eating insects is its key (Chamnan et al. 2013; Owino et al. 2015; Skau et al. 2013a, b). Proteins, vitamins and minerals are often 
Table 3 Mineral compostion [mg/100 g] (dry weight)

\begin{tabular}{|c|c|c|c|c|c|c|c|c|c|c|c|c|}
\hline \multirow[t]{2}{*}{ Species } & \multirow[t]{2}{*}{ Stage/Part } & \multicolumn{5}{|c|}{ Common elements } & \multicolumn{6}{|c|}{ Trace elements } \\
\hline & & $\mathrm{Ca}$ & K & $\mathrm{Mg}$ & $P$ & $\mathrm{Na}$ & $\mathrm{Fe}$ & $\mathrm{Zn}$ & $\mathrm{Mn}$ & $\mathrm{Cu}$ & I & $\mathrm{Se}$ \\
\hline \multicolumn{13}{|l|}{ Blattodea (cockroach) } \\
\hline Blatta lateralis & Nymph & 24.00 & 160.00 & 21.00 & 122.00 & 53.00 & & & & & & \\
\hline Periplaneta americana & Nymph & 38.50 & 224.00 & 25.00 & 176.00 & 74.40 & 1.48 & 3.27 & 0.26 & 0.79 & 0.03 & 0.03 \\
\hline \multicolumn{13}{|l|}{ Coleoptera } \\
\hline Callipogon barbatus (long-horned beetle) & Larva & 157.00 & 15.20 & 135.00 & 15.20 & 47.20 & & & & & & \\
\hline $\begin{array}{l}\text { Rhynchophorus phoenicis (African palm } \\
\text { weevil) }\end{array}$ & Larva & 54.10 & 1025.00 & 131.80 & 352.00 & 52.00 & 14.70 & 26.50 & 0.80 & 1.60 & & - \\
\hline Tenebrio molitor (Yellow mealworm beetle) & Larva & 47.18 & 895.01 & 210.24 & 748.03 & 140.94 & 5.41 & 13.65 & 1.36 & 1.60 & 0.01 & 0.07 \\
\hline Zophobas morio (superworm) & Larva & 81.02 & 750.59 & 118.29 & 562.95 & 112.83 & 3.92 & 7.29 & 1.02 & 0.86 & & - \\
\hline \multicolumn{13}{|l|}{ Diptera } \\
\hline Drosophila melanogaster (fruit fly) & Larva & 140.00 & & 130.00 & 1100.00 & & 45.42 & 14.70 & 1.61 & 0.87 & & \\
\hline Hermetia illucens (soldier fly) & Larva & 934.00 & 453.00 & 174.00 & 356.00 & 88.70 & 6.66 & 5.62 & 6.18 & 0.40 & 0.03 & 0.03 \\
\hline Musca domestica (house fly) & Adult & 76.50 & 303.00 & 80.60 & 372.00 & 135.00 & 12.50 & 8.58 & 2.66 & 1.29 & 0.01 & 0.02 \\
\hline Musca domestica (house fly) & Larva & 2010.00 & & & 1320.00 & 660.00 & 60.40 & 23.70 & 5.60 & 3.40 & & \\
\hline \multicolumn{13}{|l|}{ Hemiptera } \\
\hline Aspongubus viduatus (melon bug) & Adult & 1021.21 & 200.08 & 301.10 & 1234.33 & 401.10 & & & & & & \\
\hline Agonoscelis pubescens & Adult & 759.51 & 412.52 & 309.22 & 923.11 & 340.41 & & & & & & \\
\hline Euschistus egglestoni (stink bug) & Adult & 204.00 & 108.00 & 1910.00 & & 397.00 & 57.00 & 59.00 & & & & \\
\hline \multicolumn{13}{|l|}{ Hymenoptera } \\
\hline Apis mellifera (honeybee) & Adult & 222.90 & 1585.40 & 201.70 & 860.10 & 75.60 & 37.70 & 14.00 & & 4.60 & & \\
\hline Apis mellifera (honeybee) & Pupa & 97.00 & 2207.30 & 193.90 & 900.00 & 60.80 & 15.30 & 11.70 & & 3.70 & & \\
\hline Apis mellifera (honeybee) & Larva & 84.90 & 1871.90 & 177.00 & 782.50 & 59.40 & 13.30 & 11.60 & & 3.60 & & \\
\hline Oecophylla virescens (tree ant) & Adult & 79.70 & 957.00 & 122.10 & 936.00 & 270.00 & 109.00 & 16.90 & 6.30 & 2.17 & & \\
\hline Polybia occidentalis & Pupa & 93.00 & 54.00 & 982.00 & & 59.00 & 35.00 & 28.00 & & & & \\
\hline Bee brood & Immature stages & 59.48 & 1159.48 & 90.95 & 771.55 & 55.17 & 5.56 & 6.90 & 0.26 & 1.72 & & \\
\hline \multicolumn{13}{|l|}{ Isoptera (termite) } \\
\hline Macrotermes nigeriensis & Dewinged adults & 0.10 & 336.00 & 6.10 & 1.49 & 112.00 & 0.96 & 0.10 & 0.08 & 0.07 & & 0.00 \\
\hline \multicolumn{13}{|l|}{ Lepidoptera } \\
\hline Anaphe venata (African silkworm) & Larva & 40.00 & 1150.00 & 50.00 & 730.00 & 30.00 & 10.00 & 10.00 & 40.00 & 1.00 & & \\
\hline Bombyx mori (domesticated silkworm) & Larva & 102.31 & 1826.59 & 287.86 & 1369.94 & 274.57 & 9.54 & 17.75 & 2.49 & 2.08 & & 0.08 \\
\hline Bombyx mori (domesticated silkworm) & Pupa & 158.00 & & 207.00 & 474.00 & & 26.00 & 23.00 & 0.71 & 0.15 & & \\
\hline Imbrasia epimethea (mopane caterpillar) & Larva & 224.73 & 1258.06 & 402.15 & 666.67 & 75.27 & 13.01 & 11.08 & 5.81 & 1.18 & & \\
\hline Imbrasia truncata (mopane caterpillar) & Larva & 131.61 & 1348.44 & 192.02 & 841.42 & 183.39 & 8.74 & 11.11 & 3.24 & 1.40 & & \\
\hline Usta terpsichore (mopane caterpillar) & Larva & 391.00 & 3259.00 & 59.00 & 766.00 & 3340.00 & 39.10 & 25.30 & 6.70 & 2.60 & & \\
\hline \multicolumn{13}{|l|}{ Orthoptera } \\
\hline Acheta domesticus (cricket) & Adult & 132.14 & 1126.62 & 109.42 & 957.79 & 435.06 & 6.27 & 21.79 & 3.73 & 2.01 & & 0.06 \\
\hline Boopedon flaviventris (boopies) & Adult & 88.00 & 66.00 & 521.00 & & 173.00 & 24.00 & 32.00 & & & & \\
\hline Ruspolia differens (cricket) & Adult & 24.50 & 259.70 & 33.10 & 121.00 & 229.70 & 13.00 & 12.40 & 2.50 & 0.50 & & \\
\hline Sphenarium histrio (grasshopper) & Adult & 82.00 & 177.00 & 420.00 & & 1142.00 & 16.00 & 78.00 & & & & \\
\hline Sphenarium purpurascens (grasshopper) & Adult & 112.00 & 377.00 & 424.00 & & 609.00 & 18.00 & 42.00 & & & & \\
\hline $\begin{array}{l}\text { Recommended daily intakes [mg/day] for } \\
\text { adults }\end{array}$ & & 1300.00 & 4700.00 & 240.00 & 700.00 & $<=1500$ & 33.00 & 8.50 & 2.20 & 1.10 & & 0.03 \\
\hline
\end{tabular}

The data were summarized by the following references: Józefiak et al. 2016, Kulma et al. 2016, Finke 2005, 2013, Mariod et al. 2011, Van Huis et al.

2013, Belluco et al. 2013, Ramos-Elorduy et al. 1997, Rumpold and Schluter 2013. Mean values are shown if multiple different reports exist 
lacking in the traditional diets of developing areas, though it is essential to provide these nutrients adequately for infants and children. Farm products like vegetables and domestic livestock are often illegitimate or unaffordable for them. Insects, however, are usually cheap but with the nutrients that are deficient in traditional diets. Meanwhile, some insects are traditional food for people in certain areas. Products have thus been developed and promising results are on their way. SOR-Mite (protein-enriched sorghum porridge) project provides another insight in improving diets. In many African countries, the grains local people daily consume are lack of proteins and fats. However, these grains can balance well nutritionally with flying termites, which can be easily gathered. The porridge made of their mixtures is both nutritional and economical (Van Huis et al. 2013).

Many people from developed areas find it hard to take insects as food, but they are just uncomfortable with the original appearance of insects. Street foods containing entomic components have been developed recently, which are generally made of the mixture of crushed mealworms and flour. The products taste like insects but are presented in the shape of snacks that people are familiar with (e.g. crisps) (Hartmann et al. 2018; Tan et al. 2015). Great profits are expected if these snacks can be further developed with proper promotion.

Edible insects also serve as a feeding source for livestock and aquaculture now. It is believed that fowls fed by insects, which can provide nice protein supplies, are more nutritional than those fed by grains (Hwangbo et al. 2009; Józefiak et al. 2016; Veldkamp \& Bosch 2015). Using insects as fodders is particularly popular in areas where vegetable feeds is expensive (Krishnan et al. 2011). The cost is increasingly challenging for industries to feed farmed animals on traditional meals that are made of soy. Insect meal, however, can provide enough nutrition with cost that is distinctly low. Biomass could be recycled during the production of insects, which makes the protein sustainable. Moreover, pupae of Chironomidae and Muscidae are used as fishing baits and feeds (Awoniyi et al. 2004). Yellow mealworms have been widely used as the fodder for amphibious pets like lizards and salamanders (Liu et al. 2010; Zhou et al. 2002).

Food additives can be extracted from insects, too. Carmine, a common natural colorant being used for hundreds of years, is obtained from Dactylopius coccus (Van Huis et al. 2013). It provides a bright red dye for clothes, cosmetics and of course, food. It is commonly used in stacks like jelly. In fact, the demand of the dye has been rapidly increasing as people are keen on natural dyes at present (Baskes 2000). Similarly, the lac insect (Kerria lacca) is a fabulous source of a water- soluble polyhydroxy-anthraquinones called lac dye. The pigment is originally bright red, but can be mordant from violet to red and brown. It was primarily used in coloring textile fibre, but it is now involved in beverage industries as well (Raman 2014; Srivastava et al. 2013). Lac resin secreted by the lac insect is commonly used in coating candies and fruits (Siddiqui 2004).

Beyond being eaten to allay the hunger or just for pleasure, insect extracts can be used as a source of medicine, healthcare and industrial products (Liu \& Wei 2002). Industrial enzymes for biodiesel production have been successfully extracted from black soldier flies (Hermetica illucens). The technique is seen as a solution to energy shortage (Nguyen et al. 2018; Su et al. 2019). The exoskeleton of adults is a rich source of chitin, which has been proven to enhance the immune system of different organisms (Mack et al. 2015; Van Dyken \& Locksley 2018). More than 400 kinds of antibacterial substances have been extracted from insects. Antimicrobial peptides (AMPs)are increasingly popular recently with intensive research conducted. In fact, more than 170 defensins have been found in invertebrates and most of them can be produced from insects (Józefiak et al. 2016). House flies (Musca domestica) have been used as a source of antimicrobials. Lac resin mentioned above is actually versatile in various industries. Besides coating food, it is widely used in insulated materials, printing and adhesive industries(Siddiqui 2004; Wang et al. 2006). Moreover, it is of great value in pharmaceutical industry with the potential in hepatoprotective and anti-obesity drugs (Iqbal \& Khan 2019; Perveen et al. 2013; Sinha \& Kumria 2003; Zhang et al. 2012). White wax secreted from Chinese white wax scales (Ericerus pela) serves similar to lac resin and it is used in coating tablets (Qin 1997; Yang et al. 2012). A special oil called um-buga, which is derived from melon bugs (Coridius vidutus), contains a high amount of antibacterial substances that control gram-positive bacteria (Mustafa et al. 2008). It is only utilized in some African areas, though. The famous fungus-insect complex of Bombyx batryticatus and Beauveria bassiana is a luxury traditional Chinese medicine. It has been proven to possess multi-pharmacologic functions including anti-convulsion, anticoagulation, hypnogenesis, anti-fugus, anticancer and hypolipidemic. The active constituents extracted from it, including polysaccharides, flavones and beauvericin have been developed into modern medicine targeting corresponding diseases ( $\mathrm{Hu}$ et al. 2017; Wu et al. 2015). The medical potential of many other reared insects have been demonstrated, including several cases of antioxidants extracted from different groups of insects (Atkinson et al. 1973; Feng and Chen 2009; Zielinska et al. 2017). 


\section{Benefits - economically and environmentally}

Primarily, insects are taken as foods because of the low cost. For wild resource-rich species, harvesting is almost free. For farming species, they usually feed on a wide range of cheap fodders with efficient energy transmission. Notably, the efficiency of conversion of ingested food (ECI) of T. molitor is 53 to $73 \%$ whereas it is at most $40 \%$ in other animals (Morales-Ramos \& Rojas 2015). The carbon and water use as well as the ammonia emissions of farmed edible insects are all low compared with those of livestock, which can benefit both the economy and the environment (Halloran et al. 2016). The life cycles of insects are usually distinctly shorter than other protein sources with less breeding space needed (Klunder et al. 2012; Pimentel 1991; Ramos-Elorduy 2008; Wilkinson 2011). Contrary to the low cost, they are often sold on high prices at market, bringing great opportunities of income globally (Munthali \& Mughogho 1992; Payne 2014; Sribandit et al. 2008).

Starting farming insects does not need high start-up capital. In fact, there are many insect-farms operated by families in India and Southeast Asia (Halloran et al. 2017; Van Huis \& Oonincx 2017). The industrial production of most insects are still on their way. Farming these species in a large scale means the opening up of new industries, which would bring in opportunities of employments. Labor would be needed from production to sales. Regional income would conceivably increase in principle.

Eating insects would reduce the consumption of pesticides, especially the chemicals. Many edible insects are important pests of economical plants, which are used to be managed by insecticides. However, they would be largely caught artificially with extra profits bringing in. Consequently, the amount of next generation would be controlled by the limited amount of mating adults. As the use of pesticides decreases, the resistance insects generate to drugs will be staved off (Cerritos 2009; Kouřimská \& Adámková 2016). Organic botanic products can be supplied in the meantime. Such strategy conforms to the concept Integrated Pest Management (IPM) (DeFoliart 1997).

\section{Food security}

The utilization of edible insects is at an early to medium stage. Concerns of the potential risks were proposed, but regulations of governing insects as a source of food are still deficient globally (EFSA 2015).

Many insects have been eaten, but only very few of them have been well investigated. A full-scaled investigation of the ingredients of commonly eaten insects should be performed. On the one hand, some insects might have toxic substances like carcinogen. The thiaminase, which can cause the seasonal ataxia syndrome, has been found in larvae of African silkworms (Anaphe venata) (Adamolekun 1993; Adamolekun \& Ibikunle 1994). Toluene, a nervous system depressant toxic, has been extracted from some insect products, too. Allergies caused by eating silkworms, cicadas, crickets, wasps, grasshoppers and stinkbugs have all been reported (Belluco et al. 2013; Feinberg et al. 1956; Gaillard 1950; Ribeiro et al. 2018). Insects were actually the fourth most common allergenic offenders in China since 1980 though no deaths was reported (Feng et al. 2018). Additionally, the ingredients of insects are so complicated that they might cause cross-allergic reactions to certain groups of people. The cases are numerous and the allergies are sometimes even followed by asthma and coryza. Compositional analyses of commercial insects should be performed to understand their levels of allergens and toxins as well as the index of risk. Reliable diagnostic tools for routine detections should be popularized for the species that are harvested from nature to avoid accidental ingestion (Van Huis \& Oonincx 2017). The chemical hazards depend not only on species, but also on habitats. Insects growing in the environments with human interferences might contain pesticide residues, too.

Most edible insects contain a high amount of calories, or are enriched in a particular nutritional constituent, which makes them dangerous to certain groups of people. For example, obesity patients should avoid eating larvae of Phasus triangularis, which is composed of $77.2 \%$ of fat (Ramos-Elorduy et al. 1997). Insect products that are enriched in proteins is hazardous to gout patients. A reference like recommended daily amounts (RDAs) should be proposed for these products. Proper cooking guides are essential as well. Bouvier (1945) found the consumption of the feet of grasshoppers and locust can cause intestinal blockage, which is fatal. Hemolymph of certain groups should be removed before cooking because it is poisonous to human beings.

Standardizations of rearing the edible insects should be set in the first place. Strict management is needed. The rearing places should be sealed or filtered in order to minimize the possibility of insects running away from farms and factories, which would not only disturb the public, but also interfere with ecosystems (Van Huis \& Oonincx 2017). The process affecting the quality of insect-products should also be formalized since the composition of insects can be strongly affected by their diets and environment. It has been demonstrated that larvae of $T$. molitor would concentrate inorganic heavy metal ions from soil where they grow and become toxic (Vijver et al. 2003). The food residues in insects and insect products might be poisonous to people who are allergenic, too. Honey is popular globally. However, its quality control has been problematic. The purity of vegetation in bee forages is sometimes badly controlled, which consequently affects the quality of honey. 
Unknown toxic substances and allergens might exist in these products. The feeding has to be standardized to screen the potential risks.

Insects are usually enriched in nutrients and are conceivably a suitable environment for microorganisms to live and breed. The risk of parasites is consequently hard to avoid. Analyses have demonstrated the susceptibility of microbiological hazards in insect products without proper treatment. Various types of Enterobacteriaceae and sporulating bacteria have been found in insects (Reineke et al. 2012). Simply boiling cannot fully eliminate the risks of bacterial infection (Klunder et al. 2012). Preventive measures need to be taken during the stages of production and storage.

Additionally, the safety of food chains and nets should be considered. Like all the other organisms, stable popularity of edible insects maintains the function of the ecosystems (Payne \& Van Itterbeeck 2017). Human, however, interferes the population of insects by competing with their other predators, which impairs the regulations of ecosystems (Choo 2008; Payne \& Van Itterbeeck 2017). The ecological niche would change and ecosystems would thus go into chaos when the exploitation exceeds the regeneration capacity (Cerritos 2009). The collection should be sustainable with the biology of insects considered. It would help to ensure the presence of next generation by avoiding the collection before the mating season of adults (Cerritos 2009; Nowak et al. 2016). Cirina forda was famous for survival-endowed, scrappy and fecund. It was seen as a new cheap delicious source of protein and became popular especially in Africa. However, soon afterwards, the overharvesting started and its population became unrecoverable (Illgner \& Nel 2000; Roberts 1998; Sunderland et al. 2011; Toms \& Thagwana 2005; Van Huis 2013). Some species have always been at a low level, for instances, mayflies and caddish flies. These insects might face extinction if people continue catching them from fields for eating (Feng et al. 2018). Sometimes anthropic behaviors and abiotic factors might damage or destroy the habitats of insects. Logging would cut down trees that cater the vital needs of insects, thus influence their abundance and distribution. Improper use of pesticides has led to the continuous decline of some groups in certain areas (Dirzo et al. 2014). Climate change would affect the population of insects, too (Toms \& Thagwana 2005). The harvest should be based on the dynamics of insects to maintain their existence. In fact, raising these insects instead of only harvesting them from nature would eliminate all the risks above. There was a period that African Goliath beetle (Goliathus goliathus) was endangered because of the loss of its host trees. But it is commonly eaten now due to the prosperity of the rearing industries. People are no longer concerned about the potential threat it had towards the hosts and can thus enjoy the delicacy freely (Neuenschwander et al. 2011; Van Huis 2013).

\section{Promotion}

Improvement of marketing strategy would benefit the promotion. The market could be divided into two parts. For the price-sensitive customers, entomophagy could be an efficient way to drive down their cost of living. In order to attract these customers effectively, the money saved from acquiring similar nutrition from insects instead of other foods can be emphasized. Apparently, adding insects into their diets would be economical. The second target customers are more concerned about the quality and the flavor of food. It is essential to let these people understand that insects are similar to the traditional protein sources. Many people from developed areas, that are capable of high-level consumption, are actually not familiar with entomophagy. On the contrary, most of them have negative perceptions towards it (Kellert 1993). These might closely relate to customs, but customs can be changed by the modern people who are open-minded. Yet they need a channel to know that insects are more than food for people who need energy. Entomophagy could be a lifestyle. Workshops should be held to promote the insect products. Promotions on radio, TV shows would facilitate the implementation, too.

In the meantime, improvements of insect foods would be essential. Diversified products would definitely be intriguing for customers (Feng et al. 2018). Attentions can be attracted if fancy styles of insect cuisines and stacks are developed. Publishing guides of cooking insects have been proven to be useful, which enables people cooking their own insect cuisines at home and insects would thus become daily goods (Feng et al. 2016). In the long term, diversified products would make edible insects a daily enjoyment.

\section{Prospects}

The consumption of edible insects is continuously growing as people are increasingly interested in the new resource. However, some insects still cannot be regularly supplied since they can only be harvested from nature at present. Farming insects as food is still at an early stage though some species have successfully been reared in a large scale (Reineke et al. 2012). However, it is expected that the industry would be prosperous by the development of new insect products, the improvement of cultivation and the optimization of production.

Most edible insects are regional and rarely exported partly because the transportation of raw insects might bring quarantine issues. Only very few cases have been reported that immigrants import special local insect products from their hometown (Bukkens 1997). 
However, the ready-to-eat products can be clean and importable if they are prepared by standardard method. This requires a mature industrial line. The industrialization of edible insects is therefore the foundation of the global consumption of many insects. The insects groups eaten sometimes differ distinctly even in neighboring regions because people usually just follow their traditions, which however, brings the opportunity of developing new edible insects from native creatures (Meyer-Rochow 2005). A trend of eating longan stink bugs (Tessaratoma papillosa), which is one of the principal pests of litchi, hits southern China recently. The bug is famous for jetting smelly venom when being caught. But they are now an ambrosia to some people after proper frying or simmering. It was only consumed in Thailand, but it has successfully been promoted to warm areas where initially have the stink bugs colonized (Feng et al. 2000; Raksakantong et al. 2010). The stink bugs are thus being caught massively, which has contributed to the IPM of litchi, too.

Semi-cultivation could be a middle manipulation of obtaining edible insects that cannot be raised artificially. Eating cicadas is popular in many rural areas of China, but it is almost impossible to rear them in factories as they feed on trees. Luckily, rearing them in fields is practical, profitable without safety concerns. Insects still live in the wild but the surrounding organisms are controlled. Hosts would be taken care of to guarantee the appropriate habitats. It could maintain a sustainable production as well as protect the hosts and preys of insects. Special techniques based on the seasonality can ensure the collection, and can thus lengthen the period of producing edible insects. Doudan, the larvae of Clanis bilineata, is a traditional food and an important commercial product from Jiangsu province of China. The production is limited by temperature and the product is thus extremely expensive in winter with unstable quality (Lin et al. 2005). However, people can expect to enjoy doudan of high quality all year round if its semi-cultivation can be developed. Actually, cases have been operated in large-scaled production to obtain termites, palm weevils and caterpillars in tropical areas (Van Huis et al. 2013). The quality tests of such products, however, should be strictly performed to ensure the food safety.

Developing new farming insects is promising since there have been a large amount of edible insects reported. But it is important to keep cautious when developing new products. Traditions should be followed to gain the public perception and acceptance. Comprehensive and intensive studies of the insects would be needed to ensure the food security and avoid potential risk. The complexity level of rearing should be considered as well as the cost. For example, rearing insects growing in lentic water is easier than those inhabit in lotic water. It is obviously hard to raise insects sensitive to environments. Insects with gathering behaviors like swarming are apparently easy to be collected. It is always advocated to synthesize eco-industrial chains by rearing insects. Some species are efficient in bioconverting the organic waste like rotten fruits, e.g., black soldier fly, house fly and yellow mealworm (Cickova et al. 2015; Nguyen et al. 2015). It has been proven that the low-nutritive waste can be transformed into high-nutritive products during their growth (RamosElorduy et al. 2002). In addition to the management of wastes, their larvae and pupae can be utilized to feed cattle, pig, poultry and fish (Newton et al. 2005). It would be economical, environmental and convenient to add these insects into the production of farms. Such actions have been taken and titled "Ecodiptera project" in Europe (Van Huis et al. 2013).

Generally, farmed insects can be clean and safe enough for eating, especially the products made from insects after ecdysis. But in order to persuade the customers, optimized processing-flow including rearing, handling, drying and storage, should be individually developed for the future insect products. A clear and comprehensive framework of production would certainly be helpful in assuring the potential customers. Sanitation and health issues should be concerned. Strategies should be prepared for the potential problems, such as diseases and pests. This is not only for food safety, but also for maximizing the productivity of farming. Building networks between farms and industries would definitely be helpful, which can therefore make their production geared. For mature industries, it is worth developing new medicine and healthcare products based on extracts of insects for further profits.

\section{Conclusion}

Entomophagy is the key to solving the growing needs of nutrients globally because edible insects can provide high amounts of proteins, fats, vitamins and mineral elements with great economic and environmental advantages. Insects can serve in various areas in addition to being eaten as cuisines and snacks. Various modern products have been developed due to the intensive studies of insects. The consumption of edible insects is increasingly popular. People are consuming insects not only for nutrition, but also for fun. However, it is still concerned that the utilization of edible insects might bring health and safety issues.

The market of edible insects is not synchronous to the benefits they can bring at this stage. Strategies of promotion and production are proposed to attract and reassure the customers. Semi-cultivation is suggested as it can 
effectively boost the production of certain insects. Both farming and processing should be standardized to ensure the quality of insect products. Communications between farms and industries are advocated for efficient cooperation and further profits. Agricultural industrial integration is expected by the development of new insect products, the improvement of cultivation and the optimization of production.

\section{Abbreviations}

AMPs: Antimicrobial peptides; DRVs: Diet reference values; ECl: Efficiency of conversion of ingested food; IPM: Integrated Pest Management; MUFA: Monounsaturated fatty acid; PUFA: Polyunsaturated fatty acid; RDAs: Recommended daily amounts; SFA: Saturated fatty acid; SORMite: Protein-enriched sorghum porridge

\section{Acknowledgements}

The two anonymous reviewers and the editor Yan Huang are deeply appreciated for their suggestions and assistance during the publication which have improved the manuscript tremendously.

\section{Authors' contributions}

The study was primarily designated by HL and HS. The manuscript was drafted by $C T, C L, L W$ and FL, then modified by DY, HL and HS. All authors read and approved the final manuscript.

\section{Funding}

This study was sponsored by the Special Fund Project for Basic Scientific Research of JAAS in 2019 (Supporting Key Talents) (ZX(19)3002).

\section{Availability of data and materials}

Not applicable.

\section{Competing interests}

The authors declare that they have no competing interests.

\section{Author details}

${ }^{1}$ Institute of Leisure Agriculture, Jiangsu Academy of Agricultural Sciences, Nanjing 210014, China. ${ }^{2}$ Department of Entomology, China Agricultural University, Beijing 100193, China. Jiangsu Academy of Agricultural Sciences, Nanjing 210014, China. ${ }^{4}$ Institute of Food Safety and Nutrition, Jiangsu Academy of Agricultural Sciences, Nanjing 210014, China.

Received: 2 April 2019 Accepted: 23 October 2019

Published online: 21 November 2019

\section{References}

Adamolekun, B. (1993). Anaphe venata entomophagy and seasonal ataxic syndrome in Southwest Nigeria. Lancet, 341 (8845), 629.

Adamolekun, B., \& Ibikunle, F. R. (1994). Investigation of an epidemic of seasonal ataxia in Ikare, western Nigeria. Acta Neurologica Scandinavica, 90(5), 309-311.

Arrese, E. L., \& Soulages, J. L. (2010). Insect fat body: Energy, metabolism, and regulation. Annual Review of Entomology. https://doi.org/10.1146/annurevento-112408-085356.

Atkinson, P. W., Brown, W. V., \& Gilby, A. R. (1973). Phenolic compounds from insect cuticle - identification of some lipid antioxidants. Insect Biochemistry, 3(11), 309-315. https://doi.org/10.1016/0020-1790(73)90062-0.

Awoniyi, T. A. M., Adetuyi, F. C., \& Akinyosoye, F. A. (2004). Microbiological investigation of maggot meal, stored for use as livestock feed component. Journal of Food, Agriculture and Environment, 2(3-4), 104-106.

Baskes, J. (2000). Indians, merchants, and markets: A reinterpretation of the Repartimiento and Spanish-Indian economic relations in colonial Oaxaca, 17501821. California: Stanford University Press.

Belluco, S., Losasso, C., Maggioletti, M., Alonzi, C., Ricci, A., \& Paoletti, M. G. (2015). Edible insects: A food security solution or a food safety concern? Animal Frontiers, 5(2), 25-30.

Belluco, S., Losasso, C., Maggioletti, M., Alonzi, C. C., Paoletti, M. G. \& Ricci, A. (2013). Edible insects in a food safety and nutritional perspective: A critical review. Comprehensive Reviews in Food Science and Food Safety, 12(3), 296313. https://doi.org/10.1111/1541-4337.12014.

Blondeau, N., Lipsky, R. H., Bourourou, M., Duncan, M. W., Gorelick, P. B., \& Marini, A. M. (2015). Alpha-linolenic acid: An omega-3 fatty acid with neuroprotective properties-ready for use in the stroke clinic? BioMed Research International, 2015, 519830.

Bouvier, G. (1945). Quelques questions d'entomologie vétérinaire et lutte contre certains arthropodes en Afrique tropicale. Acta Tropica, 2, 42-59.

Bukkens, S. G., \& Paoletti, M. G. (2005). Insects in the human diet: nutritional aspects. Ecological implications of minilivestock; role of rodents, frogs, snails, and insects for sustainable development (pp. 545-577).

Bukkens, S. G. F. (1997). The nutritional value of edible insects. Ecology of Food and Nutrition, 36(2-4), 287-319. https://doi.org/10.1080/03670244.1997.9991521.

Cerritos, R. (2009). Insects as food: An ecological, social and economical approach. CAB Reviews: Perspectives in Agriculture, Veterinary Science, Nutrition and Natural Resources, 4(027), 1-10.

Chamnan, C., Skau, J., Roos, N., Dijkhuizen, M. A., Berger, J., Friis, H., et al. (2013). Body composition in relation to micronutrient status in Cambodian infants: The Winfood project. Tropical Medicine \& International Health, 18, 87.

Chen, P., Wongsiri, S., Jamyanya, T., Rinderer, T., Vongsamanode, S., Matsuka, M., et al. (1998). Honey bees and other edible insects used as human food in Thailand. American Entomologist, 44(1), 24-29.

Cherry, R. (1991). Use of insects by Australian aborigines. American Entomologist, $37(1), 8-13$.

Choo, J. (2008). Potential ecological implications of human entomophagy by subsistence groups of the Neotropics. Terrestrial Arthropod Reviews, 1(1), 81-93.

Cickova, H., Newton, G. L., Lacy, R. C., \& Kozanek, M. (2015). The use of fly larvae for organic waste treatment. Waste Management, 35, 68-80. https://doi.org/ 10.1016/..wasman.2014.09.026

DeFoliart, G. R. (1997). An overview of the role of edible insects in preserving biodiversity. Ecology of Food and Nutrition, 36(2-4), 109-132. https://doi.org/ 10.1080/03670244.1997.9991510.

Dirzo, R., Young, H. S., Galetti, M., Ceballos, G., Isaac, N. J. B., \& Collen, B. (2014). Defaunation in the Anthropocene. Science, 345(6195), 401-406. https://doi. org/10.1126/science.1251817.

EFSA, S. C. (2015). Risk profile related to production and consumption of insects as food and feed. EFSA Journal, 13(10), 4257.

Elmadfa, I., \& Kornsteiner, M. (2009). Fats and fatty acid requirements for adults. Annals of Nutrition \& Metabolism, 55(1-3), 56.

Ernst, W. H. O., \& Sekhwela, M. B. M. (1987). The chemical-composition of lerps from the mopane psyllid Arytaina-Mopane (Homoptera, Psyllidae). Insect Biochemistry, 17(6), 905. https://doi.org/10.1016/0020-1790(87)90027-8.

Feinberg, A. R., Feinberg, S. M., \& Benaim-Pinto, C. (1956). Asthma and rhinitis from insect allergens: I. Clinical importance. Journal of Allergy, 27(5), 437-444.

Feng, Y., \& Chen, X. (2009). Reviews on the research and utilization of insect health care foods. Journal of Shandong Agrcultural University (Natural Science), 40(4), 676-680.

Feng, Y., Chen, X., Wang, S., Ye, S., \& Chen, Y. (2000). The common edible insects of Hemiptera and their nutritive Forest research. Forest Research, 13(6), 608612. https://doi.org/10.3321/j.issn:1001-1498.2000.06.006

Feng, Y., Chen, X., \& Zhao, M. (2016). Edible insects of China. Beijing: Science Press.

Feng, Y., Chen, X. M., Zhao, M., He, Z., Sun, L., Wang, C. Y., et al. (2018). Edible insects in China: Utilization and prospects. Insect Science, 25(2), 184-198. https://doi.org/10.1111/1744-7917.12449.

Finke, M. D. (2005). Nutrient composition of bee brood and its potential as human food. Ecology of Food and Nutrition, 44(4), 257-270.

Finke, M. D. (2013). Complete nutrient content of four species of feeder insects. Zoo Biology, 32(1), 27-36.

Gaillard, G. E. (1950). The aphid—An insect allergen. Journal of Allergy and Clinical Immunology, 21(5), 386-399.

Gaston, K. J., \& Chown, S. L. (1999). Elevation and climatic tolerance: A test using dung beetles. Oikos, 86(3), 584-590.

Gerland, P., Raftery, A. E., Sevcikova, H., Li, N., Gu, D. A., Spoorenberg, T., et al. (2014). World population stabilization unlikely this century. Science, 346(6206), 234-237. https://doi.org/10.1126/science.1257469

Godfray, H. C., Beddington, J. R., Crute, I. R., Haddad, L., Lawrence, D., Muir, J. F., et al. (2010). Food security: The challenge of feeding 9 billion people. Science, 327(5967), 812-818. https://doi.org/10.1126/science.1185383.

Halloran, A., Roos, N., Eilenberg, J., Cerutti, A., \& Bruun, S. (2016). Life cycle assessment of edible insects for food protein: a review. Agronomy for Sustainable Development, 36(4). https://doi.org/10.1007/s13593-016-0392-8. 
Halloran, A., Roos, N., \& Hanboonsong, Y. (2017). Cricket farming as a livelihood strategy in Thailand. The Geographical Journal, 183(1), 112-124. https://doi. org/10.1111/geoj.12184.

Hartmann, C., Ruby, M. B., Schmidt, P., \& Siegrist, M. (2018). Brave, healthconscious, and environmentally friendly: Positive impressions of insect food product consumers. Food Quality and Preference, 68, 64-71. https://doi.org/10. 1016/j.foodqual.2018.02.001.

Hu, M. B., Yu, Z. J., Wang, J. L., Fan, W. X., Liu, Y. J., Li, J. H., et al. (2017). Traditional uses, origins, chemistry and pharmacology of Bombyx batryticatus: A review. Molecules, 22(10). https://doi.org/10.3390/molecules22101779.

Hwangbo, J., Hong, E., Jang, A., Kang, H., Oh, J., Kim, B., et al. (2009). Utilization of house fly-maggots, a feed supplement in the production of broiler chickens. Journal of Environmental Biology, 30(4), 609-614.

Illgner, P., \& Nel, E. (2000). The geography of edible insects in sub-Saharan Africa: A study of the Mopane Caterpillar. The Geographical Journal, 166(4), 336-351.

lqbal, B., \& Khan, N. A. (2019). Hepatoprotective and anti-hepatitis effect of non pharmacopoeial compound formulation on CCl 4-induced hepatotoxicity in albino rats. Indian Journal of Traditional Knowledge, 18(1), 47-51.

Janzen, D. H., \& Schoener, T. W. (1968). Differences in insect abundance and diversity between wetter and drier sites during a tropical dry season. Ecology, 49(1), 96

Jongema, Y. (2017). Worldwide list of recorded edible insects. The Netherlands: Department of Entomology, Wageningen University \& Research.

Józefiak, D., Józefiak, A., Kieronczyk, B., Rawski, M., Swiatkiewicz, S., Dlugosz, J., et al. (2016). Insects - a natural nutrient source for poultry - a review. Annals of Animal Science, 16(2), 297-313. https://doi.org/10.1515/aoas-2016-0010.

Kellert, S. R. (1993). Values and perceptions of invertebrates. Conservation Biology, 7(4), 845-855.

Klunder, H. C., Wolkers-Rooijackers, J., Korpela, J. M., \& Nout, M. J. R. (2012). Microbiological aspects of processing and storage of edible insects. Food Control, 26(2), 628-631.

Kouřimská, L., \& Adámková, A. (2016). Nutritional and sensory quality of edible insects. NFS Journal, 4, 22-26.

Krishnan, R., Sherin, L., Muthuswami, M., Balagopal, R., \& Jayanthi, C. (2011). Seri waste as feed substitute for broiler production. Sericologia, 51(3), 369-383.

Kulma, M., Plachý, V., Kouřimská, L., Vrabec, V., Bubová, T., Adámková, A., \& Hučko, B. (2016). Nutritional value of three Blattodea species used as feed for animals. Journal of Animal and Feed Sciences, 25(4), 354-360.

Lin, H., Wu, F., Li, S., Liu, Z., \& Wang, W. (2005). Advances on rearing method and comprehensive utilization of Clanos bilineata. Journal of Economic Animal, 9(3), 177-180.

Liu, M., \& Wei, G. (2002). The review on functional factors in I nsects and exploitation prospect of functional food. Food Science and Technology, 27, 21-25.

Liu, Y.-S., Wang, F.-B., Cui, J.-X., \& Zhang, L. (2010). Recent status and advances on study and utilization of Tenebrio molitor. Journal of Environmental Entomology, 32(106-14).

Mack, I., Hector, A., Ballbach, M., Kohlhäufl, J., Fuchs, K. J., Weber, A., et al. (2015). The role of chitin, chitinases, and chitinase-like proteins in pediatric lung diseases. Molecular and Cellular Pediatrics, 2(1), 3

Mariod, A. A., Abdel-Wahab, S. I., \& Ain, N. M. (2011). Proximate amino acid, fatty acid and mineral composition of two Sudanese edible pentatomid insects. International Journal of Tropical Insect Science, 31(3), 145-153.

Meyer-Rochow, V. (2005). Traditional food insects and spiders in several ethnic groups of Northeast India, Papua New Guinea, Australia, and New Zealand. In Ecological implications of minilivestock: Rodents, frogs, snails, and insects for sustainable development (pp. 385-409).

Morales-Ramos, J. A., \& Rojas, M. G. (2015). Effect of larval density on food utilization efficiency of Tenebrio molitor (Coleoptera: Tenebrionidae). Journal of Economic Entomology, 108(5), 2259-2267. https://doi.org/10.1093/jee/tov208.

Munthali, S. M., \& Mughogho, D. E. C. (1992). Economic incentives for conservation bee-keeping and saturniidae caterpillar utilization by rural communities. Biodiversity and Conservation, 1(3), 143-154. https:/doi.org/10.1007/Bf00695912.

Mustafa, N. E. M., Mariod, A. A., \& Matthaus, B. (2008). Antibacterial activity of Aspongopus Viduatus (melon bug) oil. Journal of Food Safety, 28(4), 577-586. https://doi.org/10.1111/j.1745-4565.2008.00132.x

Neuenschwander, P., Sinsin, B., \& Goergen, G. (2011). Protection de la Nature en Afrique de l'Ouest: Une Liste Rouge pour le Bénin nature conservation in West Africa: Red list for Benin. Ibadan: IITA.

Newton, L, Sheppard, C, Watson, D. W. Burtle, G, \& Dove, R. (2005). Using the black soldier fly, Hermetia illucens, as a value-added tool for the management of swine manure (p. 17). Raleigh: Animal and Poultry Waste Management Center, North Carolina State University.

Nguyen, H. C., Liang, S. H., Chen, S. S., Su, C. H., Lin, J. H., \& Chien, C. C. (2018) Enzymatic production of biodiesel from insect fat using methyl acetate as an acyl acceptor: Optimization by using response surface methodology. Energy Conversion and Management, 168-175. https://doi.org/10.1016/j.enconman. 2017.12.068.

Nguyen, T. T., Tomberlin, J. K., \& Vanlaerhoven, S. (2015). Ability of black soldier Fly (Diptera: Stratiomyidae) larvae to recycle food waste. Environmental Entomology, 44(2), 406-410. https://doi.org/10.1093/ee/nvv002.

Nowak, V., Persijn, D., Rittenschober, D., \& Charrondiere, U. R. (2016). Review of food composition data for edible insects. Food Chemistry, 193, 39-46. https:// doi.org/10.1016/j.foodchem.2014.10.114.

O'Dea, K. (1991). Traditional diet and food preferences of Australian aboriginal hunter-gatherers. Philosophical Transactions of the Royal Society of London. Series B, Biological Sciences, 334(1270), 233-241.

Owino, V. O., Skau, J., Omollo, S., Konyole, S., Kinyuru, J., Estambale, B., et al. (2015). WinFood data from Kenya and Cambodia: Constraints on field procedures (vol 36, pg S41, 2015). Food and Nutrition Bulletin, 36(4), Np1. https://doi.org/10.1177/0379572115624347.

Payne, C. (2014). Wild harvesting declines as pesticides and imports rise: The collection and consumption of insects in contemporary rural Japan. Journal of Insects as Food and Feed, 1(1), 57-65.

Payne, C., Scarborough, P., Rayner, M., \& Nonaka, K. (2016). Are edible insects more or less 'healthy'than commonly consumed meats? A comparison using two nutrient profiling models developed to combat over-and undernutrition. European Journal of Clinical Nutrition, 70(3), 285.

Payne, C. L. R., \& Van Itterbeeck, J. (2017). Ecosystem services from edible insects in agricultural systems: A review. Insects, 8(1). https://doi.org/10.3390/ insects8010024.

Perveen, A., Jahan, N., Wadud, A., \& Alam, M. T. (2013). Medicinal benefits of lac described in Unani literature-an overview. American Journal of Pharm Tech Research, 3(5), 1-10.

Pimentel, D. (1991). Ethanol fuels - energy security, economics, and the environment. Journal of Agricultural and Environmental, 4(1), 1-13. https://doi. org/10.1007/Bf02229143.

Qin, T.-K. (1997). 1.2. 3.2 The pela wax scale and commercial wax production. World Crop Pests, 7: Elsevier, 303-321.

Raksakantong, P., Meeso, N., Kubola, J., \& Siriamornpun, S. (2010). Fatty acids and proximate composition of eight Thai edible terricolous insects. Food Research International, 43(1), 350-355.

Raman, A. (2014). Discovery of Kerria lacca (Insecta: Hemiptera: Coccoidea), the lac insect, in India in the late 18th century. Current Science India, 106(6), 886

Ramos-Elorduy, J. (2008). Energy supplied by edible insects from Mexico and their nutritional and ecological importance. Ecology of Food and Nutrition, 47(3), 280-297.

Ramos-Elorduy, J. (2009). Anthropo-entomophagy: Cultures, evolution and sustainability. Entomological Research, 39(5), 271-288.

Ramos-Elorduy, J., González, E. A., Hernández, A. R., \& Pino, J. M. (2002). Use of Tenebrio molitor (Coleoptera: Tenebrionidae) to recycle organic wastes and as feed for broiler chickens. Journal of Economic Entomology, 95(1), 214-220.

Ramos-Elorduy, J., \& Moreno, J. M. P. (2002). Edible insects of Chiapas, Mexico. Ecology of Food and Nutrition, 41(4), 271-299.

Ramos-Elorduy, J., Moreno, J. M. P., Prado, E. E., Perez, M. A., Otero, J. L., \& De Guevara, O. L. (1997). Nutritional value of edible insects from the state of Oaxaca, Mexico. Journal of Food Composition and Analysis, 10(2), 142-157.

Raubenheimer, D., \& Rothman, J. M. (2013). Nutritional ecology of entomophagy in humans and other primates. Annual Review of Entomology, 58, 141-160. https://doi.org/10.1146/annurev-ento-120710-100713.

Reineke, K., Doehner, I., Schlumbach, K., Baier, D., Mathys, A., \& Knorr, D. (2012). The different pathways of spore germination and inactivation in dependence of pressure and temperature. Innovative Food Science \& Emerging Technologies, 13, 31-41.

Ribeiro, J. P. C., Cunha, L. M., Sousa-Pinto, B., \& Fonseca, J. (2018). Allergic risks of consuming edible insects: A systematic review. Molecular Nutrition \& Food Research, 62(1). https://doi.org/10.1002/mnfr.201700030.

Roberts, C. (1998). Long-term costs of the mopane worm harvest. Oryx, 32(1), 6-8

Rumpold, B. A., \& Schluter, O. K. (2013). Nutritional composition and safety aspects of edible insects. Molecular Nutrition \& Food Research, 57(5), 802-823. https://doi.org/10.1002/mnfr.201200735. 
Sales-Campos, H., Reis de Souza, P., Crema Peghini, B., Santana da Silva, J., \& Ribeiro Cardoso, C. (2013). An overview of the modulatory effects of oleic acid in health and disease. Mini Reviews in Medicinal Chemistry, 13(2), 201-210.

Sherman, R. A., Hall, M., \& Thomas, S. (2000). Medicinal maggots: An ancient remedy for some contemporary afflictions. Annual Review of Entomology, 45(1), 55-81.

Siddiqui, S. (2004). Lac-the versatile natural resin. Natural Product Radiance, 3(5), 332-337

Sinha, V. R., \& Kumria, R. (2003). Coating polymers for colon specific drug delivery: A comparative in vitro evaluation. Acra Pharmaceutica-Zagreb, 53(1), 41-48.

Skau, J. K. H., Bunthang, T., Chamnan, C., Roos, N., \& Ferguson, E. (2013a). The use of linear programming retrospectively to clarify if an intervention product can optimize the complementary food diet - WinFood study from Cambodia. Tropical Medicine \& International Health, 18, 195-196.

Skau, J. K. H., Chamnan, C., Touch, B., Chea, M., Unni, U., Filteau, S., et al. (2013b). Effect of animal-source foods and micronutrient-fortification complementary foods on body composition, linear growth, Iron status - the Winfood project in Cambodia. Annals of Nutrition \& Metabolism, 63, 163-164.

Sribandit, W., Wiwatwitaya, D., Suksard, S., \& Offenberg, J. (2008). The importance of weaver ant (Oecophylla smaragdina Fabricius) harvest to a local community in northeastern Thailand. Asian Myrmecology, 2, 129-138.

Srivastava, S., Ray, D., Pandey, S., Prasad, K., Prasad, M., \& Baboo, B. (2013). Pure lac dye: A potential natural food additive. International Journal of Emerging Technology and Advanced Engineering, 3, 589-594.

Su, C.-H., Nguyen, H. C., Bui, T. L., \& Huang, D.-L. (2019). Enzyme-assisted extraction of insect fat for biodiesel production. Journal of Cleaner Production, 223, 436-444.

Sunderland, T. C., Ndoye, O., \& Harrison-Sanchez, S. (2011). Non-timber forest products and conservation: What prospects? Non-timber forest products in the global context (pp. 209-224). Berlin: Springer.

Tan, H. S. G., Fischer, A. R. H., Tinchan, P., Stieger, M., Steenbekkers, L. P. A., \& van Trijp, H. C. M. (2015). Insects as food: Exploring cultural exposure and individual experience as determinants of acceptance. Food Quality and Preference, 42, 78-89. https://doi.org/10.1016/j.foodqual.2015.01.013.

Toms, R., \& Thagwana, M. (2005). On the trail of missing mopane worms. Science in Africa.

Van Dyken, S. J., \& Locksley, R. M. (2018). Chitins and chitinase activity in airway diseases. Journal of Allergy and Clinical Immunology, 142(2), 364-369.

Van Huis, A. (2013). Potential of insects as food and feed in assuring food security. Annual Review of Entomology, 58, 563-583.

Van Huis, A., \& Oonincx, D. G. A. B. (2017). The environmental sustainability of insects as food and feed. A review. Agronomy for Sustainable Development, 37(5). https://doi.org/10.1007/s13593-017-0452-8.

Van Huis, A., Van Itterbeeck, J., Klunder, H., Mertens, E., Halloran, A., Muir, G., et al. (2013). Edible insects: Future prospects for food and feed security. Roman: Food and Agriculture Organization of the United Nations.

Veldkamp, T., \& Bosch, G. (2015). Insects: A protein-rich feed ingredient in pig and poultry diets. Animal Frontiers, 5(2), 45-50.

Vijver, M., Jager, T., Posthuma, L., \& Peijnenburg, W. (2003). Metal uptake from soils and soil-sediment mixtures by larvae of Tenebrio molitor (L.) (Coleoptera). Ecotoxicology and Environmental Safety, 54(3), 277-289. https:// doi.org/10.1016/S0147-6513(02)00027-1.

Wang, X., Li, J.-Z., Fan, Y.-M., \& Jin, X.-J. (2006). Present research on the composition and application of lac. Forestry Studies in China, 8(1), 65-69.

$\mathrm{WHO}$, Protein and amino acid requirements in human nutrition: report of a joint FAO/WHO/UNU expert consultation, WHO technical report series. 2007.

Wilkinson, J. (2011). Re-defining efficiency of feed use by livestock. Animal, 5(7), $1014-1022$

Wood, J. D., Richardson, R. I., Nute, G. R., Fisher, A. V., Campo, M. M., Kasapidou, E., Sheard, P. R., \& Enser, M. (2004). Effects of fatty acids on meat quality: A review. Meat Science, 66(1), 21-32.

Wu, W. P., Cao, J., Wu, J. Y., Chen, H., \& Wang, D. (2015). Anticancer activity of Bombyx batryticatus ethanol extract against the human tumor cell line HeLa. Genetics and Molecular Research, 14(1), 79-88. https://doi.org/10.4238/2015. January.15.10.

Yang, P., Zhu, J., Gong, Z., Xu, D., Chen, X., Liu, W., Lin, X. \& Li, Y. (2012). Transcriptome analysis of the Chinese white wax scale Ericerus pela with focus on genes involved in wax biosynthesis. PLoS One, 7(4). https://doi.org/ 10.1371/journal.pone.0035719.

Yen, A. L. (2002). Short-range endemism and Australian Psylloidea (Insecta: Hemiptera) in the genera Glycaspis and Acizzia (Psyllidae). Invertebrate Systematics, 16(4), 631-636. https://doi.org/10.1071/lt01038.
Zhang, C., Tang, X., \& Cheng, J. (2008). The utilization and industrialization of insect resources in China. Entomological Research, 38, S38-S47.

Zhang, H., Fang, G., Zheng, H., Guo, Y., \& Li, K. (2011). Study on the antioxidation of lac dye. Applied Mechanics and Materials, 140, 451-458.

Zhou, W., Peng, Y., \& Sun, Y. (2002). Research on the feed transforming efficiency of Monopterus albus fed with the larva of Tenebrio molitor L. Ecologic Science, 21(3), 257-258.

Zielinska, E., Baraniak, B., \& Karas, M. (2017). Antioxidant and anti-inflammatory activities of hydrolysates and peptide fractions obtained by enzymatic hydrolysis of selected heat-treated edible insects. Nutrients, 9. https://doi.org/ 10.3390/nu9090970.

Lin, H., Wu, F., Li, S., Liu, Z., \& Wang, W. (2005). Advances on rearing method and comprehensive utilization of Clanos bilineata. Journal of Economic Animal, 9(3), 177-180.

\section{Publisher's Note}

Springer Nature remains neutral with regard to jurisdictional claims in published maps and institutional affiliations.
Ready to submit your research? Choose BMC and benefit from:

- fast, convenient online submission

- thorough peer review by experienced researchers in your field

- rapid publication on acceptance

- support for research data, including large and complex data types

- gold Open Access which fosters wider collaboration and increased citations

- maximum visibility for your research: over $100 \mathrm{M}$ website views per year

At BMC, research is always in progress.

Learn more biomedcentral.com/submissions 